EDUKACJA MIĘDZYKULTUROWA

2017, nr 1 (6)

ISSN 2299-4106

ZuZANNA BŁAJET

Piotr BŁajet

\title{
Metafora z motywem psa, czyli o bliskości odległych kultur ${ }^{1}$
}

Streszczenie: Przedmiotem rozważań tekstu są przysłowia, aforyzmy, związki frazeologiczne, wyrażenia przysłowiowe i porzekadła wykorzystujące motyw psa w opisie jakiejś cechy ludzkiej lub zjawiska świata rzeczywistego, występujące w języku polskim oraz w językach należących do irańskiej grupy językowej: perskim, tadżyckim i szugnońskim. W badaniach nad przysłowiami i frazeologią zastosowano metodę etnolingwistyczną. Wykazano istnienie znacznych podobieństw z metaforami polskimi. Z perspektywy koncepcji ucieleśnionego i osadzonego w kulturze umysłu (EEM), traktującego metafory jako reprezentacje umysłowe, świadczy to o znacznym podobieństwie tak odległych kultur, jakimi są polska i irańska. Podobieństwa te wskazują na istnienie w jakiejś głębszej warstwie faktycznej jedności doświadczenia człowieka niezależnie od różnic dzielących ludzi żyjących w różnych kulturach.

Słowa kluczowe: języki irańskie, metafora, międzykulturowość, przysłowia i frazeologia, umysł ucieleśniony osadzony w kulturze

\section{Metafora jako heurystyka}

W paradygmacie kognitywnym, zgodnie z koncepcją ucieleśnionego i osadzonego w kulturze umysłu (ang. Embodied-Embedded Mind, skr. EEM ${ }^{2}$ ) w odróżnieniu od „tradycyjnego językoznawstwa” (w dużym uproszczeniu od Arystotelesa do Chomsky'ego), metafory nie są traktowane tylko jako środki poetyckie i ozdoby retoryczne, ale jako nośniki znaczenia, narzędzia myślenia oraz działania. Metafora, zgodnie z tym paradygmatem, nie pojawia się - jak

1 W tekście wykorzystane są fragmenty pracy magisterskiej: Z. Błajet: Symbolika psa w przysłowiach i frazeologii perskiej, tadżyckiej i szugnońskiej. Kraków 2014, Uniwersytet Jagielloński, Wydział Filologiczny, Instytut Filologii Orientalnej, Zakład Iranistyki.

2 M. Hohol: Wyjaśnić umyst: struktura teorii neurokognitywnych. Kraków 2013, Copernicus Center Press, s. 125 i n. 
uważa się dość powszechnie - na poziomie języka, ale na poziomie pojęć, czyli reprezentacji umysłowych. Innymi słowy należy przyjąć, że nie tyle mówimy metaforycznie, ale metaforycznie myślimy:

Kategorie naszego myślenia są w większości metaforyczne, a rozumowanie opiera się na metaforycznych implikacjach i wnioskach, codzienny racjonalizm wymaga więc wyobraźni ${ }^{3}$.

Metaforę scharakteryzować można jako odwzorowanie, czyli symulację, znanej i opanowanej pojęciowo dziedziny źródłowej na podlegającą konceptualizacji i mniej znaną dziedzinę docelową. Na przykład możemy zastosować metaforę przestrzeni fizycznej (dziedzinę źródłową) dla wyjaśnienia przestrzeni społecznej (dziedziny docelowej): kategorie przestrzeni fizycznej, w której przedmioty znajdują się nad lub pod, wewnątrz lub na zewnątrz mogą służyć jako symulacje relacji w grupie społeczności.

Odwzorowanie to przenosi istotne cechy strukturalne pojęć ${ }^{4}$. Koncepcja metafory jako symulacji wiąże się z koncepcją EEM, zgodnie z którą umysł rozwija się dzięki aktywności cielesnej w określonym środowisku kulturowym, ale też wydaje się spójna $\mathrm{z}$ fenomenologicznymi analizami percepcji Maurice'a Merleau-Ponty, który stwierdza, że „motoryczność w stanie czystym posiada elementarną zdolność nadawania sensu (Sinngebung)" 5 .

Zdaniem autorów książki Metafory w naszym życiu większa część znanego nam systemu pojęciowego ma strukturę metaforyczną, co oznacza, że większość pojęć można zrozumieć za pomocą innych pojęć. Zgodnie z tym założeniem muszą istnieć pojęcia, które można rozumieć bezpośrednio. Pierwszymi takimi pojęciami są proste kategorie przestrzenne. Początkowym zatem etapem rozwoju ucieleśnionego umysłu będzie ucieleśnienie przestrzeni fizycznej - kategorie „nad - pod”, „przed - za”, „wewnątrz - na zewnątrz”, „blisko - daleko” itd. będą odnosić się do ciała podmiotu. Ucieleśnienie przestrzeni będzie stanowić fundament dla ucieleśnienia poznania społecznego. Wymienione powyżej przykładowe kategorie mogą służyć również do definiowania relacji społecznych: można być nad kimś w hierarchii, można komuś podlegać, można być przed kimś lub za kimś, wewnątrz lub na zewnątrz grupy, blisko lub daleko od kogoś...

3 G. Lakoff \& M. Johnson: Metafory w naszym życiu. Warszawa 2010, Aletheia, s. 251.

4 Tamże, s. 31.

5 To zdanie M. Meaurlau-Ponty: Fenomenologia percepcji. Warszawa 2001, Aletheia, s. 161. 
Teza o tym, że procesy poznawcze są ściśle związane z motorycznością i koncepcją schematu ciała, prezentowana przez Merlau-Ponty'ego, Lakkofa, zwolenników koncepcji ucieleśnionego umysłu, wzmacniana jest przez neurologiczną koncepcję neuronów lustrzanych.

Zjawisko aktywowania neuronów (odpowiedzialnych za konkretne działanie) nie tylko podczas manipulowania obiektem, ale również wtedy, gdy obiektem manipuluje inny osobnik po raz pierwszy zaobserwowano u makaków. Te neurony, które „reagują” na aktywność innego osobnika, nazwane zostały lustrzanymi. Neurony lustrzane nie reagują pobudzeniem na widok samego obiektu manipulacji, nie reagują też na symulację manipulacji bez użycia obiektu.

Z tymi spostrzeżeniami koresponduje stworzona przez Vittoria Gallesego koncepcja ucieleśnionej symulacji. Symulacja jest tu rozumiana jako „automatyczny, nieświadomy, przedrefleksyjny mechanizm funkcjonalny, którego rola polega na modelowaniu obiektów, osób i zdarzeń. To przedrefleksyjne modelowanie jest fundamentem dla powstawania treści reprezentacji umysłowych i mechanizm ten wydaje się odgrywać fundamentalną rolę kształtowaniu funkcji poznawczych. Symulacja ma zatem charakter umysłowy, a nie tylko motoryczny, ponieważ przyczynia się bezpośrednio do kształtowania treści poznawczych"6.

Metafora stanowi zatem symulację nieznanej lub mało znanej, czy trudno przewidywalnej rzeczywistości, w której to symulacji wykorzystywane są doświadczenia rzeczywistości lepiej poznanej: w zwrocie metaforycznym, powie Paul Ricoeur, „chodzi o wyrażenie pokrewieństwa tam, gdzie potoczne myślenie nie dostrzega żadnego związku" . W naszym przypadku metafora z motywem psa stanowi odwzorowanie "znanej i opanowanej pojęciowo dziedziny źródłowej" - psa, jego bytu, zachowań, relacji z człowiekiem - na „podlegającą konceptualizacji i mniej znaną dziedzinę docelową” - egzystencję człowieka, relacje międzyludzkie. Wykorzystuje się tę metaforę w celu poznawania rzeczywistości społecznej, ponieważ można przyjąć, że funkcjonowanie zwierzęcia - psa jest znacznie bardziej przewidywalne niż zachowanie człowieka. Dlaczego metafora psa, a nie innego zwierzęcia przybrała te ludzkie znaczenia? Przypuszczalnie dlatego, że pies od wielu tysięcy lat jest najbliższym człowiekowi zwierzęciem w sensie relacyjnym (patrz poniżej).

6 V. Gallese: Mirror Neurons, Embodied Simulation. "Psychoanalytic Dialogues" 2009, nr 19, s. 519-536.

7 P. Ricouer: Metafora i symbol. „Literatura na Świecie” 1988, nr 8-9, s. 245-254. 
Jak napisano powyżej, metafora, zgodnie z koncepcją EEM, jest narzędziem poznania i działania. Lakoff i Johnson w metaforyczny sposób piszą wręcz, że metafora jest tak samo istotnym elementem naszego funkcjonowania jak zmysł dotyku ${ }^{8}$. Owo „dotykanie metaforą" może spełniać funkcję hipotezy poznawczej albo sondy próbnej, a myślenie metaforyczne można traktować jako heurystykę.

Heurystyki są niezbędne wtedy, gdy logiczne analizy są niewystarczające $\mathrm{w}$ radzeniu sobie ze złożonymi problemami, a z takimi ma do czynienia jednostka w złożoności swojego bytowania i relacji w społeczności. Heurystyka - metafora jako symulacja - pozwala zapełnić „lukę percepcyjną” będącą zarówno efektem niewiedzy o tym, w jaki sposób inny, konkretny człowiek spostrzega rzeczywistość jak i skutkiem ograniczonej przewidywalności ludzkich zachowań. Ukryte, latentne, bliżej nieokreślone zdarzenie zostaje wkomponowane w ogólny wzorzec, pod który to zdarzenie może podpadać9 Tym ogólnym wzorcem w naszym przypadku są relacje społeczne cechujące się złożonością, stanowiące kontinuum: od lubienia do nielubienia, od akceptacji do braku akceptacji, od ufności do nieufności itd. Symulacja taka spełnia funkcję heurystyki, która może przybliżyć do rozpoznania i nazwania danej sytuacji. Obserwacja zachowań psa w relacji do człowieka i do zwierząt pozwala na modelowanie (obiektywizowanie) tych zachowań relacyjnych, co jest nierzadko trudnym zadaniem w przypadku relacji międzyludzkich uwikłanych w nieokreślone subtelności, w których czynnik subiektywny odgrywa zwykle ważną rolę. Po utworzeniu modeli relacji i poklasyfikowaniu ich na osi kontinuum akceptacja - wstręt, strach (od emocji propulsywnych, czyli chęci zbliżenia się do psa, aż do emocji repulsywnych, czyli przeżyć negatywnych w związku z psem) możemy dowolnie operować modelami relacji, aby szybciej i z mniejszym prawdopodobieństwem błędu właściwie rozpoznać aktualną sytuację.

Reasumując, można przyjąć, że:

- metafora służy raczej sondowaniu, a nie diagnozowaniu;

- metafora otwiera proces rozumienia, a nie zamyka go, jest na początku procesu, a nie na końcu;

- metafora wskazuje możliwe diagnozy relacji społecznych cechujących się ambiwalencją i polisemicznością;

- metafora nie mówi wprost, dlatego stanowi narzędzie heurystyczne;

8 M. Hohol: Wyjaśnić umyst: struktura teorii neurokognitywnych. cyt. wyd., s. 130.

9 Zob. tamże, s. 145. 
- metafora mówi, jak może być, a te możliwości wskazywane przez metaforę mają swoje naturalne umocowanie - w tym przypadku naturalne obserwacje zachowań mogą przekładać się na przewidywania dotyczące człowieka;

- metafora dodaje „atmosferę emocjonalną”, a przez to możliwe jest lepsze rozpoznanie sytuacji, bo dzięki otwarciu emocjonalnemu poznawanie jest pełniejsze.

\section{Uwagi metodologiczne}

Metafory powstają na poziomie ucieleśnionego umysłu, a język jest tylko formą ich ekspresji. Metaforę należy traktować jako mechanizm poznawczy, który działa w nieświadomości kognitywnej ${ }^{10}$. Takie ujęcie metafory wpisuje się w myślenie o komunikowaniu Maurice’a Merleau-Ponty'ego, który zauważa, że istnieje przedjęzykowy poziom rozumienia i komunikacji ${ }^{11}$. Można zatem mówić o takim poziomie komunikacji, dla którego język nie stanowi przeszkody i ta przedjęzykowa komunikacja ma w jakimś stopniu charakter uniwersalny. Przypuszczalnie istnieje poziom doświadczenia wspólny dla odległych i rozległych kultur i te doświadczenia mają swoje uniwersalne reprezentacje umysłowe $\mathrm{w}$ formie metafor. W rozumieniu i interpretacji metafor pojawia się jednak istotna trudność, ponieważ metafora jest wyrażana w formie językowej. Tę dwoistość metafor - po jednej stronie umocowana jest w nieświadomym doświadczeniu, po drugiej stronie chwytana jest przez język - trafnie oddaje myśl M. Merleau-Ponty'ego:

Niepodobna u człowieka wyróżnić pierwszej warstwy zachowań, które by można nazwać „naturalnymi”, a nad nim świata duchowego czy kulturowego, który jest światem ludzkich wytworów. U człowieka, chciałoby się rzec, wszystko jest wytworzone i wszystko jest naturalne - w tym sensie, że nie ma takiego słowa, takiego zachowania, które by nie zawdzięczało czegoś biologicznemu bytowi, a które by zarazem nie oddalało od prostoty życia zwierzęcego i nie odwracało sensu zachowań witalnych dzięki czemuś w rodzaju wymykania się oraz dzięki geniuszowi dwuznaczności, który mógłby służyć za definicję człowieka ${ }^{12}$.

\footnotetext{
10 Tamże, s. 130.

11 M. Merleau-Ponty: Proza świata. Esej o mowie. Warszawa 1999, Czytelnik.

12 Tamże, s. 102-103.
} 
Dlatego też w badaniu metafory należy zastosować taką metodę, która pozwoli przebić się przez jej warstwę językową, aby dotrzeć do jej przedjęzykowego znaczenia. Współautorka tego tekstu w badaniu przysłów, aforyzmów, związków frazeologicznych, wyrażeń przysłowiowych i porzekadeł perskich, tadżyckich i szugnońskich - niekiedy określanych w niniejszym artykule terminem „irańskie” 13 - wykorzystujących motyw psa w opisie jakiejś cechy ludzkiej lub zjawiska świata rzeczywistego zastosowała metodę etnolingwistyczną, zwaną też lingwistyką antropologiczną, lingwistyką kulturową lub lingwokulturologią.

Jako kierunek współczesnego językoznawstwa realizuje program badawczy nastawiony na opis relacji języka do historii i życia społecznego danego narodu, a zwłaszcza relacji jego języka do kultury. Badania przebiegały wieloetapowo i polegały na: zbieraniu przysłów i frazeologii perskiej, tadżyckiej, szugnońskiej i polskiej (na potrzeby badań współautorka zebrała i poddała analizie około 500 przysłów, aforyzmów, frazeologizmów, wyrażeń przysłowiowych i porzekadeł perskich, tadżyckich i szugnońskich oraz blisko 100 przykładów polskich z motywem psa), przekładzie zebranego materiału na język polski ${ }^{14}$, na jego analizie i interpretacji, popartych konsultacjami z osobami persko-, tadżycko- i szugnijęzycznymi, jak również wynikami wywiadów naukowych i luźnych rozmów z mieszkańcami prowincji Szugnon (Tadżykistan, GBAO) na temat sposobu postrzegania psa i ich osobistego doń stosunku, przeprowadzonych na próbie dwunastu osób w wieku od 13 do 75 lat z różnym wykształceniem, reprezentowanej przez studentów flolo-

13 Języki perski, tadżycki i szugni należą do rodzinny języków irańskich. O pierwszych dwóch wystarczy tu powiedzieć, że są językami urzędowymi Iranu i Tadżykistanu. Natomiast język szugni/szugnoni jest jednym z ośmiu języków pamirskich, które to zalicza się do po południowo-wchodniej gałęzi języków irańskich (perski i tadżycki - do południowo-zachodniej), a które występują w Tadżykistanie w Górsko-Badachszańskim Wilajecie Autonomicznym, w północno-wschodnim Afganistanie, północnym Pakistanie oraz w chińskim Regionie Autonomicznym Sinciang-Ujgur. Osobników szugnijęzycznych szacuje się dzisiaj na około 150 tysięcy. Należą do nich głównie mieszkańcy badachszańskiej prowincji Szugnon (leżącej po obu stronach rzeki współcześnie dzielącej Tadżykistan z Afganistanem), sąsiadujących z nią dolin oraz stołecznego miasta Chorog - centrum administracyjnego, naukowego i kulturowego GBAO. I ponieważ jest on najliczniej reprezentowanym językiem swojej grupy, a przy tym najlepiej przebadanym, uważa się go za główny język pamirski.

14 Przekładu wszystkich przysłów, związków frazeologicznych, wyrażeń przysłowiowych i porzekadeł perskich, tadżyckich i szugnońskich dokonała współautorka artykułu. 
gii tadżyckiej Państwowego Uniwersytetu w Chorogu, ich rodziców, babć i dziadków oraz pamirskich naukowców i ich krewnych. Znaczenia metafor wskazywane przez Pamirczyków zestawione zostały ze znaczeniem polskich metafor wykorzystujących motyw psa ${ }^{15}$.

\section{Symbolika psa w przysłowiach i frazeologii. Analiza porównawcza przysłów i frazeologii perskiej, tadżyckiej, szugnońskiej i polskiej}

Występujące we wszystkich czterech językach przysłowia, związki frazeologiczne, wyrażenia przysłowiowe i porzekadła prezentują różnoraki, często skrajny stosunek Polaków, Irańczyków, Tadżyków oraz Szugnończyków do tego zwierzęcia. Z grubsza można je podzielić na dwie grupy: te, w których psa postrzega się negatywnie, i te, które odnoszą się do niego w sposób pozytywny, przy czym tych pierwszych jest zdecydowanie więcej.

\section{Negatywne postrzeganie psa}

Zarówno w języku polskim, jak i w językach perskim, tadżyckim i szugnońskim zdecydowana większość przysłów i frazeologizmów odnosi się do psa krytycznie, co może zaskakiwać, mając na uwadze bardzo popularne w Polsce stwierdzenie, że pies jest najlepszym przyjacielem człowieka. Pies symbolizuje w nich negatywne cechy ludzi i przedmiotów albo negatywne zjawiska lub wydarzenia. Wśród nich można wyróżnić kilka podgrup w zależności od cechy lub zbioru cech (zjawisk) pokrewnych reprezentowanych w nich przez psa.

15 Na potrzeby badań autorka zebrała i poddała analizie około 500 przysłów, aforyzmów, frzeologizmów, wyrażeń przysłowiowych i porzekadeł perskich, tadżyckich i szugnońskich oraz blisko 100 przykładów polskich z motywem psa. Spośród nich wybrano te, które - po pierwsze - charakteryzują psa, tzn. odnoszą się do jakiejś jego cechy, a po drugie - są najbardziej popularne, czyli pojawiają się w więcej niż jednym zbiorze. W artykule pominięto zatem te przysłowia i frazeologizmy, w których wprawdzie pojawia się motyw psa, ale nie odnoszą się one do żadnej z jego cech (na przykład: polskie przysłowie: niejednemu psu [na imię] Burek, perskie: psem jest ten, który z psem wchodzi do wora, czyli kto się z kim zadaje, taki sam się staje (pers. sag ast ān ke bā sag ravad dar ğavāl lub szugnoński związek frazeologiczny: laska w psi ogon (szugn.: kud dhom-ard moth) oznaczający: pośpiesznie opuścić miejsce, jak pies, którego uderzono laską w ogon; szybko wstać z miejsca i wyjść; „dawać drapaka”) oraz te, które poświadcza tylko jeden zbiór, pozostawiając owe najbardziej popularne. 
W polskich przysłowiach i frazeologii pies symbolizuje najczęściej kogoś (coś) nieważnego, lekceważonego, poniewieranego i poniżanego, niezasługującego na godziwe traktowanie. Polacy, jeżeli już pomiatają, to jak psem, jeśli bezlitośnie wypędzają lub zabijają, to też „jak psa”. Kogoś, kogo nie szanują, kim gardzą, kogo uważają za człowieka bezwzględnego, maja za psa. Podobnie w Iranie - jeśli Irańczyk zachowa się jak polski ostatni pies, to „zepsi się” (pers. sagī kardan), czyli postąpi z kimś parszywie, bezlitośnie. Jeśli w Szugnonie kogoś się poniża lub lekceważy, mówi się, że traktuje się go jak psa (szugn. yi čây kud thédow) ${ }^{16}$.

O kimś obojętnym po polsku mówi się, że pies z nim tańcowat, a jak coś nic niewarte, to jest po prostu psa warte lub co najwyżej psu na budę zda się. Polskie przysłowia i frazeologia wymownie kojarzą psa z kijem i głoszą: tyle psu kija, co i chleba oraz zauważają, że ludzie bija psa, że kij w ręku trzymaja, nie, że winien, oraz że ktoś się chroni przed czymś jak pies przed kijem.

Podobnie w przysłowiach i frazeologii perskiej, tadżyckiej i szugnońskiej. Niemal identycznie jak Polak powie Irańczyk: Kto chce psa uderzyć, ten zawsze kij znajdzie (pers. čūb be sar-e sag bezanī.. peydā mišavad). Jeśli Irańczyk zabija ze szczególnym okrucieństwem, to też jak psa (pers. sagkošì kardan). Tadżyckie przysłowie mówi: na psie mięso psie zęby (tadż. gūšt - i sag dandon-i sag), co oznacza, że pies jest wart tyle, co jego mięso, czyli nic niewart (islam traktuje psa i psie mięso jako rytualnie nieczyste [ar. harām] i zakazuje swoim wyznawcom jego spożywania. Jest zatem psie mięso dla muzułmanów nic niewarte). Odnosi się ono do dwóch złych osób (rzeczy) wartych siebie nawzajem. W przysłowiu tym pies symbolizuje właśnie m.in.

16 Zastosowana w artykule transkrypcja dla języków perskiego i tadżyckiego jest nieco zmodyfikowanym zapisem opracowanym przez autorów podręcznika do nauki języka perskiego. A. Pisowicz, M. Fraçyon: Fârsi, materiały do nauki języka perskiego. Kraków 1995, UJ. Natomiast transkrypcję języka szugni opracowała autorka na własne potrzeby robocze. Nie pretenduje ona do bycia zapisem międzynarodowym, ani ostatecznym, w pewnej mierze wykorzystuje polskie reguły zapisu. W zapisie rosyjskich tytułów książek zastosowano transkrypcję dostępną na stronie internetowej Wydawnictwa Naukowego PWN. Wszystkie imiona i nazwiska obcego pochodzenia oraz nazwy miejscowości (również te, które nie posiadają oficjalnej wersji polskiej) zapisano w wersji spolszczonej, np. Dehchodo (zamiast Dehxodā); Alamszojew (zamiast Alamšojev). Zastosowane w artykule skróty oznaczają: pers. - perski/e, tadż. - tadżycki/e, szugn. - szugnoński/e, pol. - polski/e, przysł. - przysłowie/ia, zw. fraz. - związek/ki frazeologiczny/e, wyraż. przysł. - wyrażenie/a przysłowiowe, porzek. porzekadło/a, afor. - aforyzm(y). Symbol „ " oznacza, iż przekład na język polski jest przekładem zbliżonym. 
kogoś (coś) o niskiej wartości, niegodnego uwagi. Podobnie w szugnońskim przysłowiu: Od babskiego gadania pies zdecht (z głodu) (szugn. kaxoygāp-and kud mūgżğ), które oznacza zająć się rozmową i stracić poczucie czasu, „zagadać się" i zapomnieć o swoich obowiązkach, np. o nakarmieniu psa, oraz w porzekadle: $z$ decht pies (nie mylić z polskim!; szugn. Kud mūgżğ), które oznacza mniej więcej tyle, co polski związek frazeologiczny pies kogoś (coś) drapat (jechat, tracat).

W tej podgrupie pies symbolizuje kogoś (coś) mało istotnego, niezasługującego na szacunek i godziwe traktowanie, kogo (co) się lekceważy, kim (czym) się gardzi.

W Iranie, Tadżykistanie i całym bodajże świecie muzułmańskim nazwanie kogoś psem uchodzi za jedną z najgorszych obraz. Okazuje się, że w chrześcijańskim - przynajmniej polskim - również. W języku polskim niemało „psich” obelg i wyzwisk, w których pogardę wobec drugiej osoby można wyrazić przy pomocy prostego zwrotu ty psie. Zwrot ten można rozbudowywać, stosując przeróżne określenia typu: ty psie pogański lub zbójecki, ty wściekty, zapowietrzony albo parszywy psie. Obraźliwe jest również nazwanie kogoś psim synem lub psim nasieniem.

Podobnie rzecz się ma w językach perskim, tadżyckim i szugni, w których funkcjonują właściwie identyczne obelgi: po persku i tadżycku można o kimś powiedzieć, że jest psu podobny lub psiej natury (pers. sagsefat, tadż. sagmaniš), czyli grubiański, nieuprzejmy, zły, kłótliwy, a po szugni o człowieku parszywym, podłym (ale również nieczystym) mówi się: pies nieczysty (szugn. kud-i palit).

Motyw przysłowiowego pieskiego życia często powtarza się zarówno w przykładach irańskich, jak i polskich. W obydwu przypadkach symbolizuje, najogólniej mówiąc, życie marne i nędzne, życie pełne trudów, bez powodów do radości. Na przykład po szugni powie się z psim trudem (szugn. ba yi kud -azob), czyli z dużym trudem żyć, pracować itd. „Żyć psim swędem” oznacza żyć mimo wszystko, mimo przeciwności. Ktoś, kto podle się czuje lub ma złe samopoczucie, czuje się pod psem lub jak zbity pies, a w Iranie - po prostu jak pies (pers. hāl-e sag). O człowieku przeżywającym trudne chwile po persku mówi się, że ma gorszy dzień niż pies (pers. rūz-e kasī az ruz-e sag badtar ast). Oprócz tego Irańczycy smucq się jak pies (pers. mesl-e sag pašimān šodan). Gdy ktoś zmarnieje, wykolei się moralnie, zbiednieje (a miejsce podupadnie), mówi się po polsku, że zszedt na psy. O kimś bardzo głodnym lub zmęczonym - że głodny lub zmęczony jak pies. Z kolei zdychać jak pies oznacza umierać w nędzy i opuszczeniu. Pieskie życie kończy się pieską śmiercią. 
Pies symbolizuje nadto mało istotne przeciwności losu, przeszkody życiowe, potencjalne problemy, zagrożenie, nieszczęście; kogoś (coś), kto (co) bezskutecznie próbuje nam przeszkodzić i cieszy się z nieszczęścia innych. Przysłowia i frazeologizmy wyrażają to w sposób metaforyczny i - co ciekawe - we wszystkich czterech omawianych tu językach w niemalże identyczny sposób - polskie przysłowia zdają się kalką perskich, tadżyckich czy szugnońskich lub na odwrót. I tak tymi potencjalnymi problemami, przeciwnościami losu, zagrożeniem czy przeszkodami jest pies, który swym ujadaniem chce zatrzymać karawanę, ewentualnie przechodnia ${ }^{17}$.

Gdy opinia lub nieżyczliwe działania jednych nie mają wpływu na działanie drugich lub gdy coś się dzieje pomimo protestów, i w Polsce, i w Iranie, i w Tadżykistanie mówi się, że psy wyją, a miesiąc świeci (pers.: māh fešānad nūr-o-sag 'ow'ow konad; tadż.: moh fišonad nur-u-sag av-av kunad). W Polsce psi szczekot nie ma również wpływu - à propos bezskutecznych prób przeszkadzania - na słońce (pies szczeka na słońce, a słońce świeci), a w Iranie i Tadżykistanie - na chmury. Jak ujął to jeden z perskich klasyków:

Księżyc blask rozsiewa, a pies wyszczekuje,

Każdy na swa miarę dzieto demonstruje.

Chmury czarnej, na niebie rozsnutej het,

Ujadanie psiej sfory nie zlikwiduje.

(przekład B. Bielkiewicz)

Można jeszcze powiedzieć, że psie głosy ani nie ida $w$ niebiosy, ani nawet nie pogorszą losu żebraka (pers.: āvāz-e sagān kam nakonad rezq-e gedā-ra; tadż.: ovoz-i sagon kam nakunad rizq-i gado-ro).

Zaskakujące, jak wiele przysłów nie tylko polskich, ale perskich, tadżyckich i szugnońskich również odwołuje się do takich cech naszego „najlepszego przyjaciela", jak nielojalność, nieszczerość, niewierność, zdradliwość, podłość, niewdzięczność, interesowność, wredność. Irańskie przysłowia pouczają, że zapewne nie byłby pies taki miły, gdyby miał wybór, ponieważ psy sa milutkie z powodu swej niemocy (pers. sagān az nätavānāì mahrebān-and) oraz że nażarty pies zapomina o swoich obowiazkach (pers. sag agar ğald budì va farbe, yak šekorī namāndi anda rdeh; sytego psa nie zaciagniesz na polowanie) oraz zarozumiatym się staje (tadż. sag ki ser šod, sarkaš mešavad).

17 Po polsku: psy szczekaja, karawana idzie dalej; po persku: pies ujada, a karawana idzie dalej (sag lāyad va kārvān migozarad); po tadżycku - identycznie jak po polsku (tadż.: sag mečekad va korvon megozarad); po szugni: pies szczeka, a przechodzień idzie dalej (szugn.: kud ğaqt-at rāyen agżğìst). 
Szugnończycy mówią, że jeśli nie dasz psu jeść, pójdzie w długa (szugn. Kud-ard xurok nadhädhe, yu saglak sůd), a Polacy - że pies za (na) darmo nie szczeka albo że pies macha ogonem nie do ciebie, ale do twego chleba. Irańczycy wiedzą, że ten pies lepszy, co głodnym pozostaje, ponieważ nasycony niebezpiecznym się staje (pers. sag ān beh ke xähande-ye nānbüvad // chū sìr-aš konī, došman-e ğān būvad).

Krew serca swego psu memu oddałem, boć oddanego znajomka mieć chciatem.

Bo żem nie wiedziat, że pies krwia opity dopiero będzie, psubrat, jadowity.

(przekład B. Bielkiewicz)

W Polsce kogoś nieszczerego i nielojalnego porównuje się do psa, który się łasi, a kasa, a przysłowia: strzeż się psa, co milczkiem kąsa oraz zje pies psa, kiedy nie ma mięsa przestrzegają przed obłudnikami. Mówi się jeszcze, że ktoś łże jak pies (jak słusznie zauważył W. Kopaliński, porównanie „absurdalne, ale używane na co dzień"). A na pewno już nie można wierzyć cudzemu psu, cudzemu koniowi i cudzej żonie $e^{18}$.

$\mathrm{Na}$ tym podobieństwa się nie kończą. Oprócz wymienionych wyżej negatywnych cech i niepożądanych zjawisk, w przysłowiach i frazeologii tak polskiej, jak i irańskiej pies symbolizuje: upór i nieustępliwość, zadziorność i kłótliwość, zawiść, skąpstwo i chciwość (przy czym do trzech ostatnich zdecydowanie częściej odwołują się przysłowia polskie).

Polskie gryźć się jak dwa psy, gryźć się jak pies o kość; szugn. określenie szczeniaki (o dzieciach, które się kłócą, szugn.: kudbucən), szugn. zw. fraz.: stawać się psim synem (kłócić się, drzeć koty, szugn.: Kud-kudak settow); pers. i tadż. określenie: psu podobny (czyli m.in. kłótliwy, pers. sagsefat, tadż. sagmizoğ).

Po polsku kogoś, kto sam nie zje i drugiemu nie da, nazywa się psem ogrodnika. Człowieka chciwego i zawistnego porównuje się również do psa leżącego na paździerzu lub sianie (by pies na sianie: sam go nie je, a krowie nie da). W Szugnonie o kimś skąpym i chciwym powie się, że jest psiej natury (szugn. kudgari); w szugnońskim przysłowiu: jedzqc kość, pies boi się swojego ogona (szugn. kud sitxůn xirt-at as xu zibo aks kişt) zwierzę to jest symbolem m.in. skąpstwa (oraz podejrzliwości i pozytywnie postrzeganych: ostrożności, gotowości i czujności). Natomiast w Iranie i Tadżykistanie o zawistnej natu-

18 W. Kopaliński: Stownik symboli. Warszawa 1990, WP, s. 320. Według perskiego przysłowia, wściekły pies, obok kłótliwej żony i pękniętego muru, jest jedną z rzeczy, której należy się bać (pers. az zan-e salìte, dìvār-e šekast-e va sag-e dìvāne bāyad tarsid). 
rze psa opowiada przysłowie: „pogrzeb” osła weselem dla psa (pers. be marg-e xar būvad sar-rā arusī; tadż. marg-i xar arusi-i sag ast), czyli nieszczęście jednych bywa powodem do radości innych.

Ponadto w przysłowiach i frazeologii pies jest symbolem: agresji i waleczności (motyw ten - choć niezwykle rzadko - pojawia się również w przykładach perskich), tułaczego trybu życia (o kimś, kto dużo wędruje, mówi się, że błaka się jak pies [szugn. darikud]), łakomstwa i obżarstwa (psa od słoniny, pijaka od flaszy nietatwo odstraszyć; zje pies psa, kiedy nie ma mięsa).

Pol. przysł.: psa w cieśni źle drażnić, a jeśli nie masz kija, szkoda psa drażnić; o kimś zajadłym i nieustępliwym mówi się natomiast, że ma psi charakter.

Pers. przysł.: jeśli nie masz kija, szkoda psa drażnić [pers.: čūn nām-e sag barī čūbì be dast ār ke čūn 'ow'ow konad, zan bar dahān-ǎ́]). Szczerzącego kły psa można unieszkodliwić już to wspomnianym kijem, już to ochłapem (przysłowie: gryzacemu psu, żeby nie gryzt, rzucajq ochtap [tadż.: ba sag - i gazanda luqma mepartoyan ki nagazad; szugn: pirendiğ kud-ard loqma pitéwan māpirent], gdy groźny pies kty pokazuje, ty mu wtedy rzuć kość [pers.: sag-e darande čūn dandān konad bāz to hālì ostoxān piš-aš andāz]). W koń$\mathrm{cu}$, jak głosi przysłowie irańskie: lepsza psia gęba przyssana do miski (pers.: dahān-e sag be loqmedūxtebeh; tadż.: dahan-i sag ba luqma duxta beh).

W przeciwieństwie do przysłów i frazeologizmów irańskich, nie pojawia się w polskich przykładach pies jako symbol niedbałości, nieudolności, lenistwa, opieszałości i niefrasobliwości, człowieka niezdecydowanego, który zwleka z podejmowaniem działania i przede wszystkim - bodajże najbardziej wyeksponowany w przykładach irańskich - motyw psa jako zwierzęcia nieczystego i brudnego. Irańskie przykłady wyraźnie wskazują: psich resztek nie sposób zaakceptować (tadż. pasmonda-i sag qobil-i tahorat nest); lew ich nie tknie (tadż. naxürad šer nimxürda-i sag). Naczynie polizane przez psa nie nadaje się do użytku (pers. zarfī ke sag lìsad qäbel-e este'māl nīst), a choćby wymyć psa wodą, nie stanie się czysty, wręcz przeciwnie - zacznie cuchnąć jeszcze bardziej (afor. pers. i tadż.: sag ke be āb tar šavad, palïdtar šavad). Jego krew jest nieczysta. Zetknięcie się z nią nie tylko skala, ale również - według dawnych wierzeń - przyniesie pecha (pers. xun-e sag šum ast). O podłym, parszywym człowieku Szugnończycy powiedzą: pies nieczysty. Jest pies również zwierzęciem brudnym, obrzydliwym i budzącym odrazę.

Przysł.: przez psia nieudolność lis wskakuje na dach (tadż. az noqobili-i sag rūboh ba bom meparad; szugn.: as noloyiqi-ye kud rưpcak pi diš̌̉d zibint); wspomniane już przysł. pers. i tadż.: sytego psa nie zaciagniesz na polowanie; szugn. przysł.: od czekania pies się starzeje (szugn. kud as faltowpirsůd). 
Nie zje lew tego, co porzucit pies // choćby miat w męce gtodu paść w jaskini (Sadi), pers.: Naxūradšernimxūrda-i sag, // Va-ar ba saxtībimiradandarghor ${ }^{19}$;

Przysłowia: gdzieżby psi pysk miat zabrudzić wodę rzeki (pers. āb-e daryā az dahān-e sag koğā gardad palìd) używa się w odniesieniu do kogoś (czegoś) niegodziwego, plugawego, kto (co) próbuje nam przeszkodzić, a którego (czego) działania nie przyniosą mu zamierzonych efektów.

W tej podgrupie przysłów i frazeologizmów pies symbolizuje również profanację oraz - poprzez zestawienie z meczetem - bezbożność i brak poszanowania dla świętości.

Gdy dopadnie psa potrzeba, zaśnie w meczecie (pers.: ăgal-e sag ke āyad be masğed xāb konad) lub gdy dopadnie psa potrzeba, obsika w meczecie mihrab (tadż.: ağal-i sag ki rasad, ba mexrob-i masğid mešošad). Należy tu zaznaczyć, że z punktu widzenia islamu zaśnięcie w meczecie, nie wspominając już o oddawaniu moczu, jest grzechem.

Opisany powyżej stosunek do psa wywodzi się najpewniej z muzułmańskiego przekonania o jego nieczystości. Nie zaskakuje zatem fakt, że i w przysłowiach, i frazeologii podkreśla się tę właśnie jego cechę.

\section{Pozytywne postrzeganie psa}

Drugą, zdecydowanie mniej liczną grupę przysłów, frazeologizmów, wyrażeń przysłowiowych i porzekadeł - i dotyczy to tak przykładów polskich, jak i irańskich - stanowią te, które wykorzystują motyw psa w celu zaprezentowania pozytywnych cech lub zjawisk.

Bodaj najbardziej popularnymi cechami przypisywanymi psu w Polsce są, bezsprzecznie pozytywne, wierność i przywiązanie do właściciela. Mówi się, że pies jest najlepszym przyjacielem człowieka, nieodstępującym swojego pana na krok (stąd pol. zw. fraz.: chodzić za kimś jak pies oraz leżeć u nóg jak pies, czyli być posłusznym i wiernym). W odniesieniu do kogoś niezwykle wiernego i oddanego można użyć zwrotu wierny jak pies. Podobnie sprawa się ma w Iranie i Tadżykistanie. Wśród Tadżyków i Szugnończyków panuje przekonanie, że człowiek, szczególnie płci żeńskiej, powinien uczyć się wierności od psa; pies - w przeciwieństwie do kobiety - jest wierny (tadż. sag vafo dorad, zan nadorad). Nawet jeśli Irańczyk pogardza psem, to przyzna, że jeśli

19 Cytat z: M. Fozilow: Farhang-i zarbulmasal, maqol va aforizmho-i toğiki-i forsī. T. II. Duszanbe 1997, Donisz, s. 367. 
o wierność chodzi - lepszy pies niż nikt, ponieważ pies wie na czym polega wierność, człowiek - nie.

Jednocześnie - i sprzeczność ta występuje we wszystkich czterech językach - pies jest w swej wierności naiwny. Polskie przysłowie wyraźnie mówi, że byś swemu psu i noge ucią (przecie on z toba pójdzie).

Przykłady irańskie częściej niż polskie, które prócz wierności, oddania i czujności (czujny jak pies) nie odwołują się właściwie do innych pozytywnych cech psa, odnoszą się do psa przychylnie. Natomiast wiele motywów przewijających się w przysłowiach i frazeologii perskiej, tadżyckiej i szugnońskiej funkcjonuje w świadomości Polaków. Na przykład pies jako symbol ochrony, straży, troskliwości, gotowości do obrony swojego (przysłowie perskie i tadżyckie: $w$ drzwiach domu każdy pies jest lwem [pers.: bar dar-e xāne har sagì šìr ast; tadż.: bar dar-i xona har sage šer ast]), uznanie dla jego umiejętności bezbłędnego odnajdywania się w terenie, siły i wytrzymałości fizycznej. Ta ostatnia bywa przez Szugnończyków postrzegana negatywnie; niekiedy łączy się ją ze służalczością. O kimś wytrzymałym fizycznie, naiwnie znoszącym wszystkie trudy, dający się wykorzystywać mówi się, że jest psiej natury (szugn. kudğůn).

$* * *$

Wyniki analizy porównawczej polskich i irańskich przysłów i frazeologii z motywem psa mogą zaskakiwać. Jej rezultatem, jak również rezultatem rozważań i przemyśleń własnych powstałych na różnych etapach badań nad przysłowiami i frazeologią oraz symboliką psa są następujące wnioski:

Po pierwsze: okazuje się, że pomimo ogromnej odległości zarówno geograficznej, jak i kulturowej, dzielącej Polskę od świata irańskiego, wiele przykładów polskich ma swoje odpowiedniki w językach perskim, tadżyckim i szugni.

Niekiedy, chociaż to niezwykle rzadkie, zdarza się, że polskie przysłowie lub frazeologizm sprawia wrażenie kalki perskiego, tadżyckiego czy szugnońskiego, czyli jest wyrażone dokładnie w taki sam sposób. Na przykład przytoczone już przysłowie psy (pies) szczekaja, karawana idzie (jedzie) dalej występuje we wszystkich czterech językach. Tak samo polski i szugnoński związki frazeologiczne traktować kogoś jak psa (szugn. yi čāy kud thédow) oraz polski i tadżycki psie krasomówstwo (tadż. sagdahonī kardan).

Po drugie: w zdecydowanej większości przykładów pies występuje jako symbol negatywnych cech: m.in. nielojalności, nieszczerości, zdradliwości, interesowności, wredności, służalczości, nieczystości oraz negatywnych 
zjawisk, np.: przeciwności losu, potencjalnych problemów, zagrożenia i nieszczęścia. Ponadto pies symbolizuje coś lub kogoś o niskiej wartości, mało istotnego, niezasługującego na szacunek i godziwe traktowanie. Życie psa jest symbolem życia pełnego trudów, marnego, nędznego i niełatwego, bez powodów do radości.

Po trzecie: jedynie nieliczne przysłowia i frazeologizmy wykorzystują motyw psa w celu zaprezentowania pozytywnych cech i zjawisk. I tak zwierzę to symbolizuje m.in.: wierność, oddanie, przywiązanie; niektóre przykłady uwydatniają rolę psa jako towarzysza człowieka i jego obrońcy; jest on zwiastunem bezpieczeństwa i osiedlenia. Oprócz tego odnoszą się do takich cech psa, jak wyostrzone zmysły i - co za tym idzie - umiejętność odnajdywania się w terenie, wytrzymałość fizyczna oraz upór (w pozytywnym znaczeniu). Przy czym zdecydowanie częściej w pozytywnym świetle przedstawiają psa przykłady irańskie niż polskie.

\section{Zakończenie}

Analiza metafor z motywem psa w tak odległych od siebie językach, jakimi są języki irańskie i polski, może z jednej strony wskazywać na uniwersalność ludzkiego doświadczenia. Może to być efektem mieszania się kultur w związku z wędrówkami między kontynentami ${ }^{20}$.

$Z$ drugiej strony rezultaty tych analiz są dość silnym argumentem przemawiającym na korzyść koncepcji ucieleśnionego i osadzonego w kulturze umysłu (EEM) i, co się z tym wiąże, metafory jako narzędzia myślenia i działania.

Jeśli metafora jest ekspresją umysłu ucieleśnionego i dostrzegamy zbieżność metafor w różnych kulturach, to można przyjąć istnienie prajedności człowieka na poziomie umysłu ucieleśnionego, czyli możemy mówić o występowaniu zjawiska, które można by określić praglobalizacją. Na co dzień możemy nie zdawać sobie sprawy z tego, jak wiele łączy ludzi pochodzących z odmiennych (jak się okazuje, do pewnego stopnia) kultur - może być w jakimś stopniu związane z przekazem płynącym z wystaw antropologicznych

20 W Eurazji po ustąpieniu zlodowacenia (ok. 11 tys. lat p.n.e.) układ równoleżnikowy pasm górskich (poza Uralem) umożliwiał rozprzestrzenianie się upraw roślinnych i hodowli zwierząt oraz wędrowanie ludzi: wzdłuż równoleżników panują podobne warunki klimatyczne, co ułatwia adaptację hodowli, natomiast odmienności klimatyczne są poważną przeszkodą dla ekspansji „południkowej” (w osi północ-południe). J. Diamond: Nowa naukowa synteza historii człowieka. W: J. Brockman (red.): Nowy renesans. Granice nauki. Warszawa 2005, CiS. 
w muzeach, które eksponują to, co odróżnia różne kultury, a rzadko akcentują podobieństwa.

Wydać może się zaskakujący, dominujący negatywny stosunek do psa wyrażany w metaforach, podczas gdy w potocznym myśleniu pies ma raczej konotacje pozytywne. Jak można to tłumaczyć? Być może związane jest to z dwoistością natury psa: z jednej strony pies jest zwierzęciem udomowionym od wielu tysięcy lat i najbardziej z wszystkich zwierząt „uczłowieczonym", ale drugiej strony dostrzegamy (podejrzewamy) w nim cały czas pierwiastek dzikości, nieprzewidywalności (na przykład pies spuszczony ze smyczy w lesie nierzadko staje się na powrót dzikim zwierzęciem). Postawa wobec psa explicite - świadoma jest pozytywna, natomiast w swojej warstwie nieświadomej może być silnie zabarwiona lękiem, a to z kolei znajduje swoje ujście we wrogim nastawieniu implicite. Jest tak w przypadku człowieka cywilizacji zachodniej - Polaka, jak i mieszkańca Pamiru. Może to świadczyć, mimo występowania oczywistych różnic, o faktycznej bliskości odległych (nie tylko w sensie przestrzeni) kultur.

\section{Bibliografia}

Alamszo M., Karamszo D.: Xugżnuni ziv. Chorog 2000, Pomir.

Awesta. Przekład: Peterson J. H.; http://www.avesta.org/vendidad/vd13sbe. htm_(20.05.2015).

Bachtibekow T.: Grammatika zabon-i szughnonī. Duszanbe 1979, Donisz.

Bielawski J., Machalski F., Tryjarski E.: W oazie i na stepie: myśli muzutmańskiego Wschodu. Warszawa 1958, WP.

Bielkiewicz B.: Szugnon. Dawniej - Chanat Szugnoński. Kraków 2015, publikacja wydana przez autora.

Błajet P.: Ciało jako kategoria pedagogiczna. W poszukiwaniu integralnego modelu edukacji. Toruń 2006, UMK.

Błajet P.: Ciało w kulturze wspótczesnej. Watki socjopedagogiczne. Olsztyn 2005, WSIiE TWP.

Błajet Z.: Symbolika psa w przysłowiach i frazeologii perskiej, Kraków 2014, UJ, niepublikowana praca magisterska.

Boldyrjew A. N.: Badachszanskij fol'klor. W: Sowietskoje wostokowiedienije. T. V. Moskwa - Leningrad 1948, Akademia Nauk SSSR.

Boyce M.: Zaratusztrianie: wiara i życie. Łódź 1988, WŁ. 
Brockman J. (red.): Nowy Renesans. Granice nauki. Warszawa 2005, CiS.

Broimszojewa Qimatszojewna M.: Bovarho va ta'birho dar zabonho-i šughnonī-rūšonī: taxlil-i etnolingvistī. Duszanbe 2012, Donisz.

Bubnowa M. A.: Kul't ognija i domasznich żywotnych $w$ wierowanijach driewnich pamircew. W: Awiesta w istorii i kulturie Central'noj Azii. Duszanbe 2011, Donisz.

Burszta J.: Przedmowa. W: O. Kolberg: Przystowia. Warszawa 1977, LSW.

Davaran F.: Continuity in Iranian Identity. Resilience of a cultural heritage. Abingdon 2010, Routledge.

Fârsi: materiaty do nauki języka perskiego. A. Pisowicz, M. Fraçyon. Kraków 1995, UJ.

Fozilow M.: Hikoyaho-i zarbulmasal. Duszanbe 1967, Donisz.

Fozilow M.: Zarbulmasal-u-maqolho dar tamsil-u-hakoyaho. Duszanbe 1973, Donisz.

Gallese V.: Mirror Neurons, Embodied Simulation. "Psychoanalytic Dialogues" 2009, No. 19.

Hadisy. Zbiór: S. al Buchari; www.sahihalbukhari.com (1.02.2014).

Hamrojew N.: Maqol va zarbulmasaho-i sokinon-i Pomir. W: Toğikiston. Duszanbe 1960.

Hohol M.: Wyjaśnić umyst: struktura teorii neurokognitywnych. Kraków 2013, Copernicus Center Press.

http://ganjoor.net/saadi/golestan/gbab1/sh4/

http://so.pwn.pl/zasady.php?id=629697

http://www.avesta.org/vendidad/vd13sbe.htm

http://www.iranicaonline.org/articles/dog\#pt1

http://www.sahihalbukhari.com

Józefowicz-Niedźwiecka Z.: Perskie cnoty i niecnoty. Warszawa 1999, „Dia$\log$ ".

Karamszojew D.: Alifboho-i favri zabonho-i pomirī bo namunaho-i adabī. Chorog 1992, Pomir.

Karamszojew D.: Olimon-i sovietī dar bora-i Pomir. Duszanbe 1975, Donisz. Kolberg O.: Dzieła wszystkie. Przysłowia. Wrocław 1968, LSW.

Kolberg O.: Przystowia. Warszawa 1977, LSW.

Koran. Przekład J. Bielawski. Warszawa 1986, PIW.

Krzyżanowski J.: Mądrej głowie dość dwie słowie. Pięć centuryj przysłów polskich $i$ diabelski tuzin z hakiem. T. I. Od Abrahama do Nieboszczyka. Warszawa 1994, PIW. 
Krzyżanowski J.: Przysłowie. Łódź 1960, PZWS.

Lakoff G., \& Johnson M.: Metafory w naszym życiu. Warszawa 2010, Aletheia. Lewin I. G.: Masal va afsonaho dar bora-i hayvonot. W: Kulliyot-i folklor - $i$ toğik. T. I. Moskwa 1981, Akademia Nauk SSSR.

Merleau-Ponty M.: Fenomenologia percepcji. Warszawa 2001, Aletheia.

Merleau-Ponty M.: Proza świata. Esej o mowie. Warszawa 1999, Czytelnik.

Obidow D.: Zarbulmasal va maqolaho-je darizabonon-i Afghoniston. Duszanbe 2011, Donisz.

Ofaridajew N.: Toponimiya-i ta'rixi-i Kūhiston-i Badaxšon. Duszanbe 2010, Donisz.

Qurbonchonowa Mirasanowna N.: Ustura-i ğonvaron dar folklor-i Badaxšon. Duszanbe 2011, Donisz.

Ricouer P.: Metafora i symbol. „Literatura na Świecie” 1988, nr 8-9.

Rizwonszojewa Nuraliszojewna G.: Afsonaho-i sehromez-i Badaxšon. Duszanbe 2011, Donisz.

Samnoni M.: Zarb-ol-masalhā-ye manzūm-e fārsī. Duszanbe 1995, Donisz. Szakarmamadow N.: Fol'klor-i mardum-i Pomir. T. I. Duszanbe 1992, Donisz. Szakarmamadow N.: Fol'klor-i Pomir. T. II. Duszanbe 2005, T. III, 2012, Donisz.

Szamlu A.: Ketāb-e Kūče. Teheran 1979, Mazjar.

Szirinowa R.: Mušohida doir ba zarbulmasalho-i mardum-i Badax̌̌on.

W: Sprawozdania z Konferencji Młodych Uczonych. Duszanbe 1974, Donisz.

Szirinowa R.: Oid ba zarbulamasal va maqolho-i Šughnon. W: W. Chuszenowa, Ch. Kurbanow (red.): Pomiršinosī. Maśalaho-i filologiya. Duszanbe 1975, Donisz.

Świrko S.: Wstęp. W: O. Kolberg: Dzieła wszystkie. Przysłowia. Wrocław 1968, LSW.

Zarubin I. I.: Szugnanskije teksty i slowar'. Moskwa - Leningrad 1960, Akademia Nauk SSSR.

\section{A metaphor with the dog motif - about the closeness of distant cultures}

Abstract: The article presents an analysis of Polish and Iranian (Persian, Tajik and Shughni) proverbs, idiomatic and proverbial phrases and sayings about the dog, where the dog theme is used in order to clarify certain human traits and 
phenomena of the real world. In the study an ethno-linguistic approach has been used. The Iranian examples demonstrate large similarity to Polish ones. From the perspective of the conception of the embodied-embedded mind in which metaphors are considered as a mental representations we note the existence of the unity of the human experience regardless of the differences between people living in different cultures.

Key words: Iranian languages , metaphor, interculturalism, proverbs and phraseology, embodied-embedded mind

Translated by Zuzanna Błajet, Piotr Błajet 